Name for AIDS virus

SIR - Although I personally believe that the virus associated with acquired immune deficiency syndrome (AIDS), HTLV/LAV, has enough structural and functional similarities with the other human T-lymphotropic viruses (HTLV-I and HTLV-II) to justify its classification within the same family ${ }^{1}$, I also recognize that more than just science and logic are at stake over the recent nomenclature debate $^{2}$. If a more non-partisan name is ultimately called for, my personal suggestion is that the virus should be called human AIDS/lymphotropic virus (HALV). Human, because in the tradition of naming retroviruses, the species name is given; AIDS, because although it is not the only disease this virus causes, it is the one that gives it notoriety; lymphotropic, because this is the most basic and neutral characteristic of the virus. Since it looks enough like HTLV, and contains all three letters of LAV, it may well be the perfect solution for the two groups to meet halv way.

FLOSSIE WONG-STAAL Laboratory of Tumor Cell Biology, National Cancer Institute, Bethesda, Maryland 20205, USA

1. Wong-Staal, F. \& Gallo, R.C. Blood 65, 253-263, (1985). 2. Marx, J.L. Science 227: 1449-1451, (1985).

\section{Aid for Chile}

SIR - As you probably know, we in Chile are at present in great distress. On the evening of 3 March, Santiago suffered a catastrophic earthquake. An international campaign has already started, mainly to solve the immediate needs of the several hundred thousands of homeless people. The building of our physics department, although still standing, was severely damaged, most probably beyond repair.

Science in general and physics in particular are vulnerable in developing countries and clearly more so in situations like the present one. We scientists are often looked upon with suspicion and we cannot at present expect any significant help from the authorities.

Nevertheless, we have not lost our optimism and desire to carry on with our work. After assessing the real effects of the earthquake on our building we have decided to start a campaign to raise funds in order to build up a new one. We estimate that the basic need of the thirty physicists in our department could be met by a twenty thousand square foot construction.

We would welcome any material help or advice that our colleagues in the scientific community can offer.

LINCOYÁN GONZÁLEZ

Physics Department,

University of Chile,

Casilla 5487,

Santiago, Chile \section{Embryo research}

SIR - I am disgusted with your call for research ideas on human embryos (Nature 7 March, p.11). Any researcher participating in it (and those experimenting on human tissue obtained at abortions) should be forced to read Trevor-Roper's book review "Seas of unreason" (Nature 313, 407; 1985).

The primary objective for any physician has to be care for the individual patient. We must not sacrifice human individuals for a potential benefit to others. Just as we do not kill AIDS patients to prevent the infection of others, experimentation with and killing of embryos and fetuses cannot be justified by potentially interesting research results. A statement of what those benefits might be is therefore irrelevant.

If human societies ever become aware again of those hippocratic truths, many of today's researchers will be judged then as are Third Reich doctors today. And we will ask disgustedly again, in the words of Trevor-Roper: "How could a civilized nation, in the twentieth century, not only permit it but actually cooperate in it?'”.

\section{Massachusetts General Hospital,} Boston, Massachusetts, 02114, USA

SIR - I read the News and Views article on human embryo experimentation (Nature 7 March, p.11) with incredulity.

Those of us who are not wholly in agreement with Enoch Powell's bill may believe that there are circumstances in which extreme necessity may make experiments of this type allowable. But your anonymous columnist is inviting scientists to invent research to do upon embryos: to dream up ideas, which might not otherwise have occurred to them, for research projects which would not otherwise have taken place.

Surely the ethical dubiousness of this incitement to experiment can only strengthen public opposition to all such experiments?

50 Highbury, Jesmond, Newcastle upon Tyne NE2 3EA, UK

\section{Suitable treatment}

SIR - In a recent leading article about the unauthorized implant of an artificial heart, Nature describes the stereotypes being impressed upon the surgeon and the Food and Drug Administration (FDA) as the rugged individualist and the pin-headed bureaucrat. In the same vein Nature's role could be described as the aloof and bloodless intellectual. Stripped of its urbanity, what your editorial really said was: let the patient die. Nature admits the implant functioned, and that the proper role for future implants may indeed be to stabilize patients awaiting appropriate transplants. Your objections to its use are very thin.

The issue of informed consent seems to me to be very artificial. Informed consent had been obtained in advance for a very ag- gressive procedure, a transplant. Do you really feel that even in the calm period before the surgery the patient and family would have objected to the possible use of an artificial heart on a temporary basis? The issue of FDA approval would seem very abstract and irrelevant to a family who felt that the implant had a good chance of working for the short time required.

The issue of use of a non-approved device should be put into perspective. Use of drugs for purposes not approved by the FDA is common practice in the United States. A good example is xylocaine, which is approved only as an anaesthetic, but has proved very valuable in controlling certain cardiac arrhythmias. It has been used effectively and apparently safely in that mode all over the country, and no one has said a word. Physicians use it, in some cases, because it saves patients who might otherwise die. Artifical hearts have captured the public imagination and so have engendered intense scrutiny of their use. The issues are no different from those dealt with in a more flexible way every day.

The idea that the surgical team could have been prepared with an authorized back-up is ludicrous. The cost would be astronomical, and the personnel and time are not there. The fact is that FDA has authorized a procedure, the transplant, without the possibility of the implant backup that may be needed. Placed in this impossible situation different surgeons will react in different ways. I would prefer my surgeon to be the rugged individualist not dominated by the pin-headed bureacrat. Nature's aloofness, either at the bedside or funeral, would not be welcome.

EATON E. LATTMAN

The Johns Hopkins University,

Department of Biophysics,

School of Medicine,

Baltimore, Maryland 21205, USA

\section{Dinosaurs did well}

SIR - I am a layman, but I am tired of hearing about "theories" (really mere conjectures, as they cannot be tested) of the extinction of the dinosaurs.

They ruled the roost for a hundred million years, ample time for the opposition to get its act together, for the evolution of small, elusive animals that destroyed vegetation and ate the dinosaurs' eggs so that they died of hunger faster than they could reproduce.

They died out "suddenly" did they? How can we know? For any traces to survive, the animal had to die in very special circumstances, so the absence of evidence proves nothing. And how many hectares of the Earth have been excavated?

This kind of nonsense may be good clean fun for the palaeontologists; but people in the media seem to think that $I$ wish to hear of it. I do not.

23 Eltham Road,

R. C. HOPE

London SE12 8ES, UK 